\title{
The Effect of Cutting Temperature on Carbide Drilling Life in the Process of CFRP/Steel Stacks Drilling
}

Vitalii Kolesnyk ${ }^{1}$, Dmytro Kryvoruchko ${ }^{1}$, Michal Hatala ${ }^{2}$, Dusan Mital $^{2}$, Zuzana Hutyrova ${ }^{2,}{ }^{3}$, Jan Duplak², Mohammed Alowa $^{2}$

${ }^{1}$ Department of Manufacturing Engineering, Machines and Tools, Sumy State University, Rymskogo-Korsakova 2 st., 40007 Sumy, Ukraine. Email: kol-vitaliy@ukr.net, dmytro.kryvoruchko@gmail.com

${ }^{2}$ Technical University of Kosice, Faculty of Manufacturing Technologies, Bayerova 1, Presov 080 01, Slovakia.

${ }^{3}$ Nanotechnology Centre, VSB - TU Ostrava, 17. listopadu 15/2172, Ostrava-Poruba 708 33, Czech Republic.

The fiber reinforced plastic (CFRP) are widely used in stacks with metallic materials. The parts are usually bolted together during assembling procedure. That is why drilling is one of the most widely used operations for machining of CFRP/metal and metal/CFRP stacks. That allows to obtain components, which combine high strength and low weight. This paper presents tool wear study based on the drilling experiment of CFRP/ steel stack. The most common problems of CFRP/metal stacks machining are CFRP delamination, fiber pull - out, thermal degradation and intensive tool wear. Last decade such parameters of CFRP/metal stacks drilling as axial force and torque are in the focus of researches. However, the cutting temperature in the drilling process of CFRP/metal stack and its influence on drill bit wear is still not fully gained at the present time. The purpose of current study is to investigate the effect of cutting temperature on the tool life of carbide drill. The temperature was measured with $K$ type thermocouple which was embedded on the flank surface of the drill. Axial force was measured with dynamometer. Data of cutting temperature and axial force was digitalized with analog - digital converter (ACD) and visualized on personal computer (PC). The dominating tool wear mode when drilling CFRP/steel - was flank wear which was measured with optical microscope. The experimental study of cutting temperature effect on the tool wear of carbide drill was established. It was found that the most unfavourable combination of stack materials in the conditions of drill wear is CFRP/metal.

Keywords: Composite Materials, Stack, Drilling, Cutting Temperature, Wear, Tool Life

\section{Acknowledgements}

The authors appreciate the financial support of Slovak Academic Information Agency in the framework of National Scholarship Program and also, Airtech Company and Ecolan Ingredients LLC for raw material supply.

\section{References}

[1] JENNISE, T.T., YUHAZRI, M.Y., SIHOMBING H., YAHAYA, S.H. (2013). M Gravity Effects of Curing Angle on Laminated Composite Structures: A Review on Novel Study. In: Adv Mat Sci Eng; Vol. 2013, pp. 1-10.

[2] BOLDT, J.A., CHANANI, J.P. (1995). Solid-tool machining and drilling. In: Engineered Materials Handbook, Vol. 1, pp. 667-672.

[3] PARK, K.H., BEAL, A., KIM, D., KNOW, P., LANTRIP, J. (2011). Tool wear in drilling of composite/titanium stacks using carbide and polycrystalline diamond tools. In: Wear, No 271, pp. 2826-2835.

[4] VASILKO, K., SIMKUlET, V. (2012). Phemonem of twist drill. In: Manufacturing Technology, Vol. 12, pp. 281-285.

[5] KYNCL, L., et al. (2014). Tests of drills during drilling holes into alloy wheels. In: Manufacturing Technology, Vol. 14, pp. 554-561.

[6] SHEIKH-AHMAD, J.Y. (2008). Machining of Polymer Composites. Springer, New York, pp. $122-131$.

[7] FARAZ, A., BIERMANN, D., WEINERT K. (2009). Cutting edge rounding : An innovative tool wear criterion in drilling CCFRP composite laminate. In: International Journal of Machine Tools \& Manufacture, No 49, pp. 1185-1196.

[8] PRABHU, P., JAWAHAR, P., BALASUBRAMANIAN, M., MOHAN, T.P. (2013). Machinability Study of Hybrid Nanoclay-Glass Fibre Reinforced Polyester Composites. In: International Journal of Polymer Science, Vol. 2013, pp. 1-11.

[9] MANKOVA, I., VRABEL, M., BENO, J., KOVAC, P. (2013). Application of taguchi method and surface response methodology to evaluate of mathematical models to chip deformation when drilling with coated and uncoated twist drills. In: Manufacturing Technology, Vol. 13, pp. 492-499. 
[10] REIMANN, R. (1988). Bearbeitung von faserverstarkten Kunststoffen bei hohen schnittgeschwindigkeiten. In: Technische Mitteilungen. -: Organdes Hausesder Technik, Vol. 81, pp.240-243.

[11] ZITOUNE, R., KRISHNARAJ, V., COLLOMBET, F. (2010). Study of drilling of composite material and aluminum stack. In: Composite Structures, No 92, pp. 1246-1255.

[12] KUMAR, M., PRABUKARTHI, A., KRISHNARAJ, V. (2013). Study on Tool Wear and Chip Formation during Drilling Carbon Fiber Reinforced Polymer (CFRP)/ Titanium Alloy (Ti6Al4V) Stacks. In: Procedia Engineering, No 64, pp. 582-592.

\section{Paper number: M201562}

Copyright (C) 2015. Published by Manufacturing Technology. All rights reserved. 